primary roots of the cereals do not die off early but remain intact and vital until the beginning of harvest.

Mme. Krasnosselsky-Maximov has attempted to elucidate the internal causes delaying reproduction in the winter forms of cereals. She is led to the conclusion that the winter forms contain a substance, possibly a hormone, which causes delay in reproduction.

The specific nature of the studies on moisture relations can only be briefly indicated. Ivan Vasiljev has a study of the influence of drought upon carbo. hydrate transformations in wheats. As usual, hydrolysis is increased with desiccation and synthesis with improvement in the water supply. J. N. Kondo has studied the influence of external, as well as internal, developmental factors, upon resistance to drought, whilst S. Kolotov examines the influence of soil moisture as a growth factor, and S. M. Ivanov attempts to determine the frost resistance of plants by changes in the electrical conductivity of the sap induced by frost injury.

\title{
Priestley Celebration at the Chemical Society
}

$\mathrm{P}$ RIESTLEY commemoration discourses were delivered before the Chemical Society on April 6 by Sir Philip Hartog, Prof. A. N. Meldrum, and Sir Harold Hartley, and there was also an exhibition of manuscripts, portraits, medals, books, apparatus, and personal mementoes lent by the Royal Society, Dr. Alexander Scott, Mr. G. H. Gabb, Mrs. Arundell Esdaile, Mr. W. C. Priestley, Dr. C. H. Spiers, and Dr. J. A. Newton Friend, or in the possession of the Chemical Society. Unfortunately, few of Priestley's instruments survive, as nearly all of them, together with his books and manuscripts, were destroyed when rioters sacked his house at Farhill, Birmingham, in 1791 .

Sir Philip Hartog dealt particularly with Priestley's own peculiar personality and history as a seientific man and theorist, and said that in some ways he had been singularly misjudged. Priestley had an amazing facility for mastering different subjects. $\mathrm{He}$ published some fifty works on theology, thirteen on education and history, about eighteen on political, social, and metaphysical subjects, and twelve books and some fifty papers dealing with physics, chemistry, and animal and vegetable physiology. He also knew Latin, Greek, French, German, Italian, Hebrew, Chaldee, Syrian, and began Arabic. The main purpose of his life was one of religion and piety ; his love of science, which he regarded as a relaxation, became obvious at a very early stage. $\mathrm{He}$ was the pioneer of the introduction of the teaching of science in schools.

Priestley had a clear vision of the value of hypothesis in scientific investigation, and repeatedly expressed his views on the relation of speculation to facts. Sir Philip Hartog examined and totally rejected the familiar statement that Priestley was 'unable to grasp' the new ideas of the composition of water, showing that he was at one time a convert to those ideas, that his attitude was based on his experimental observations, and that he declared himself ready to be influenced by any new and stronger evidence. Sir Philip Hartog summarised his brief appreciation of Priestley's personal qualities in the words : "Priestley was a glory not only of British science, but of British manhood".

Prof. Meldrum divided his discourse into two parts, showing in the first that Priestley, by his work on gases, made a contribution to science that is unique, and in the second exhibiting his work on nitrogen peroxide. $\mathrm{He}$ began by examining two problems which arose in the seventeenth century and were pursued in the eighteenth century by Hales, Black, and Cavendish: the absorption and production of air in general, and the existence of gases distinct from air and from one another. Priestley, who owed much to Cavendish, was self-trained in experimental science; he made the remarkable admission that his knowledge of chemistry was poor and that he was "not a practical chemist". Chemistry, up to his day, had been concerned so much with solids and liquids that its learning and processes were of little avail in work upon strange gases. Priestley was unique in being the first to handle gases boldly, easily, and quickly. Discussing what is meant by the 'discovery' of a substance, Prof. Meldrum said that Priestley got no credit for the discovery of nitrogen peroxide. He then gave an account of Priestley's preparation of nitric acid, his experiments on nitric oxide and nitrogen peroxide, and his production of nitro-sulphuric acid. The work showed his ardour for discovery, the resources of his mind, and his clever hands that nothing could escape.

Sir Harold Hartley said that Priestley's great service to chemistry was the extensiveness of his work, which revealed to chemists the variety of substances which could exist in the gaseous state, thoir individuality, and the importance of the part they played in chemical reactions. Priestley often ascribed his discoveries to chance, but in this he was unfair to himself, as he had a real genius for taking advantage of the opportunities that fortune offered him, and many of his researches showed that he could follow up a clue with a fine logical piece of investigation. Sir Harold Hartley described some of Priestley's work in connexion with the composition of the atmosphere, with the analysis of air, and with the practical applications of his discovery of oxygen. Priestley determined the relative density of gases, examined the combination of gases by volume, used solubility determinations as a means of identification, measured coefficients of thermal expansion and the conductivity of sound in gases, compared thermal conductivities, made the first experiments on gaseous diffusion, performed experiments with electricity, and was the first photo-chemist.

The secret of Priestley's genius as an investigator was his enthusiastic energy and curiosity, his fertility of mind, the ingenuity and enterprise with which he devised new experiments with the simplest means, his keen observation, his exceptional visual memory, and the rapidity with which he could develop a new investigation. There was behind everything the impelling force of his love for science, his devotion to experiment, and his boundless faith in the possibilities of new scientific discoveries. Dante's phrase well described Priestley's eager restless spirit, fearless and untiring in the defence of liberty and in the quest of truth: "con l'ali snelle ... del gran disio". 